\title{
In Silico Approach for Lead Identification and Optimization Of Antidiabetic Compounds
}

\author{
Shabana bibi ${ }^{1}$, Saima Kulsoom ${ }^{2}$, Hamid Rashid ${ }^{* 1}$ \\ ${ }^{1}$ Department of Bioinformatics, Mohammad Ali Jinnah University, Islamabad, Pakistan \\ ${ }^{2}$ Department of Chemistry, Quiad-e-Azam University, Pakistan
}

\begin{abstract}
Diabetes is the group of metabolic diseases and today is the $3 r d$ leading cause of death in humans. In the present study the problem of designing most effective antidiabetic drug was solved by using computer aided drug designing (CADD) technique. Molecular docking studies of antidiabetic compounds were carried out with human target protein having pdb id: $3 Q 6 E$ in order to find out the most active antidiabetic drug having high inhibitory activity. Docking of 59 selected compounds having antidiabetic activity was done with the active site of protein $3 Q 6 E$ and a most active lead compound was identified on the basis of strong binding interaction with target protein and $I C_{50}$ value from the selected compounds. Three type of interactions were calculated by using VMD; Hydrogen bonding, hydrophobic and ionic interactions. Four analogues of the lead compound were designed to enhance its activity against diabetes. Analogues were docked with protein $3 Q 6 E$ by using AutoDock Vina and their interactions showed that they could use as antidiabetic agent with suitable drug-like properties as compared to other active drugs for diabetes and therefore could be recommended for further studies.
\end{abstract}

Keywords: Molecular docking, diabetes, lead compound, analogous design.

\section{Introduction}

Diabetes is a multifactorial disorder of the pancreas, in which the pancreas fails to perform its function to produce insulin hormone properly in the body. It involves multiple disorders like hyperglycemia, glycosuria, abnormal metabolism of lipids, carbohydrates and proteins [1,2]. There by affecting the human body at physiological, physical and social level. It has been known as 3rd leading cause of death in humans along with other diseases such as cancer, cerebrovascular and heart diseases [3] of the major two types of diabetes: Type 1 also called as Insulin dependent diabetes mellitus, its cause is hereditary by nature and treated with insulin injections externally. The basis of Type 1 diabetes mellitus is the immunological destruction of pancreatic cells leading to deficiency of insulin in body [4].and Type 2, "Adult type" known as Non-insulin dependent diabetes that mostly common in aged people. It is treated by diet control and oral hypoglycemic medicine.

Hypoglycemic medication is helps to lower the blood sugar level in body or treat the other severe symptoms and complications of diabetes mellitus [2].

The basic mechanism of antidiabetic medications is stimulating insulin production from the pancreas or increasing the sensitivity of the body cells to insulin and is commonly used along with insulin. Different classes of anti-diabetic drugs available in market that includes insulin secretagogues known as sulfonylureas and meglitinides. Insulin sensitizers are biguanides, thiazolidinediones and metformin, and important inhibitors are $\alpha$-glucosidase inhibitors include acarbose and miglitol etc. The side-effects of these medications include extreme hypoglycemia, liver cell injury, lactic acidosis, digestive discomfort, permanent neurological deficit, headache, dizziness and even death $[5,6]$. The basic challenge in curing diabetes is to maintain blood glucose level close to normal levels [7].These therapies are used as monotherapy or in combination for optimal control of glycemia [8]. As mentioned before that these drugs are normally expensive and come with side effects.

These drugs have their limitations such as their pharmacokinetic properties, secondary failure rates and relative bad effects $[9,10]$. Thus, the need for a new efficient class of compounds to reduce the side-effects. Search for alternative drugs which will $b$ most effective for diabeties is still at an on-going phase [11]. Mother Nature may prove to be a useful source of new oral hypoglycemic compounds for the progress of pharmaceutical entities or as dietary adjunct to prevailing therapies which has less side effects [12-14,].

Identifying the exact target for the treatment of diabetes is one of the hotspots of research in the past few years. The targets used by scientists are Dipeptidyl peptidase IV (DPP IV), Glycogen phasphorylase, Protein Tyrosine Phosphatase 1-Beta (PTP-1B), Glucokinase, Peroxisome Proliferator-activated Receptor (PPAR) - $\gamma$ etc. Protein - Ligand docking studies have widely been used for structural based drug designing for Diabetes mellitus [15].Ganugapati et al studied docking studies of green tea flavonoids through Auto Dock 4.0 and Argus lab 4.0.1., and concluded that epicatechin acts as a strong insulin receptor activator [16]. Another potential target is Protein tyrosine phosphatase-1B (PTP1B) - an intracellular receptor PTP which is a significant negative regulator of the insulin signaling pathways. A PTP1B inhibitor may serve as a novel approach for the treatment of Type 2 diabetes [17]. So, PTP1B inhibitors are prospective pharmaceutical agents for treatment of 
type II diabetes, cancer and obesity. In the last decade, numerous PTP1B inhibitors have been designed as drug candidates [18]. Thiazolidinedione (TZD) compounds class exhibit properties as antidiabetic compounds [19].

Standard drugs such as rosiglitazone and pioglitazone are insulin-sensitizing medicine that function as peroxisome proliferator that activates the receptor $\gamma$ (PPAR $\gamma$ ) agonists, and in clinical situations have been proved to be effective candidates in treatment of Type 2 diabetes. Moreover, some 2, 4-TZDs have been shown to be good PTP1B inhibitors works against diabetes [20].

With the rapid increase in biological and chemical information, CADD has been dramatically reshaping research and development pathways in drug candidate identification. Use of computational techniques in drug discovery and development process is widely appreciated in terms of implementation, time and money [21].Molecular docking is a competent tool for novel micro molecule drugs discovery for targeting protein [22].

Molecular Docking of protein structures involve various possibilities of association are tried and verified on the basis of energy value, and the conformation with the least energy value is titled 'best match' i.e. having best interaction of protein with ligand. Docking strategy plays a significant role in modern drug discovery. Kuntz et al contributed immensely in docking research to improve the computational speed and accuracy. One of the areas in molecular docking is protein-ligand docking, which is gaining fame due to its role in structure based drug design [23-29]. Molecular docking is basically a computational method that predicts non covalent association of macromolecules with a receptor and a small molecule (ligand) efficiently. The method starts unbound structures, structures acquired from MD simulations, or homology modeling, etc. The prediction of binding of small molecules to proteins has huge impact for the prediction results are used to filter virtual libraries of drug-like molecules to identify leads for further drug development. Docking can even be used to calculate the bound conformation of known binders, in case the experimental holo structures are not available [27].

Many antidiabetic agents have been discovered through the use of bioinformatics tools and databases such as QSAR, Docking and Homology Modeling etc. There are many Computer Aided Drug Design and Medicinal Chemistry tools that's benefitted researchers to design novel drug candidates for diabetes. This study has been carried out in order to identify effective, selective and efficient antidiabetic Lead compound and its analogues. ChemDraw [30], AutodockVina [31] and visual molecular dynamics (VMD) [32] were used for studying molecular docking and ligand-protein interactions, respectively.

\subsection{Target Selection}

\section{Materials and methods}

Identification and selection of most appropriate drug target is the major step to initiate the drug desiging. Bioinformatics tools can be used to identify the required protein target specifically linked to the human diseases. Insulin protein is considered as target protein for this study. Its structure was taken from RCSB Protein Data Bank (PDB) by pdb ID. 3Q6E [33] shown in fig 1.

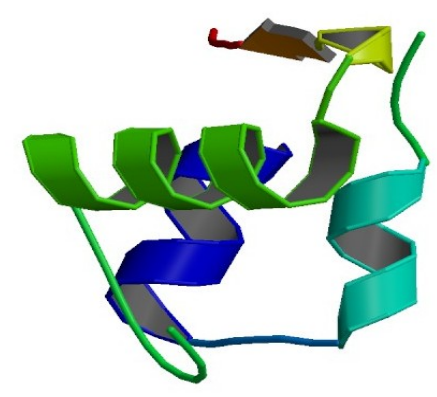

Figure 1. Structure of target (PDB ID 3Q6E) [34]

\subsection{Dataset Collection}

There are 25 standard drugs of diabetes are selected from PubChem for study. It is a public database contains validated chemical structures and detailed information of drugs. The test set was selected from literature consist of 59 compounds [34-37].

Chemical structures of standard drugs and the selected test set were made by Chem Draw Ultra 8.0 [38]. Compounds were drawn and saved in cdx format, then converted to pbd format through Chem3D Ultra 8.0. Datasets of compounds with their $\mathrm{IC}_{50}$ values are shown in table 1 and table 2. 
Table 1. Chemical structures and $\mathrm{IC}_{50}$ values of training set

\begin{tabular}{|c|c|c|c|c|c|c|c|}
\hline $\begin{array}{l}\text { S.N } \\
\text { O }\end{array}$ & Compounds & Structure & $\mathrm{IC}_{50}$ & S.NO & Compounds & Structure & $\mathrm{IC}_{50}$ \\
\hline S1 & Aleglitazar & & 0.019 & S2 & Alogliptin & & 0.0034 \\
\hline S3 & Dapagliflozin & & 0.00049 & S4 & Diprotin & & 3 \\
\hline S5 & Duloxetine & & 0.003 & S6 & Glimepride & & 0.1 \\
\hline S7 & Glipizide & & 0.398 & S8 & Glyburide & & 0.0038 \\
\hline S9 & Linagliptin & & 0.0001 & S10 & Metformin & & 20 \\
\hline S11 & Miglitol & & 0.11 & S12 & Nateglinide & & 1.667 \\
\hline S13 & Phenformin & & 27 & S14 & Pioglitazone & & 0.114 \\
\hline S15 & $\begin{array}{l}\text { Pyrrolindine- } \\
\text { 2-carbonitrile }\end{array}$ & & 0.007 & S16 & Repaglinide & & 0.106 \\
\hline S17 & Saxagliptin & & 0.006 & S18 & Sitagliptin & & 0.0035 \\
\hline S19 & Tolazamide & & 5.106 & S20 & Vildagliptin & & 0.0035 \\
\hline S21 & Voglibose & & 0.07 & S22 & $\begin{array}{l}\text { Pyrrolidine } \\
\text { derivatives }\end{array}$ & & 0.006 \\
\hline S23 & Ertiprotafib & 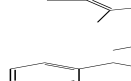 & 1.6 & S24 & Trodusemine & & 1 \\
\hline S25 & $\begin{array}{l}2 \text { 2-[4'-(2- } \\
\text { Benzyl- } \\
\text { benzofuran- } \\
\text { 3-yl)-3,5- } \\
\text { dibromo- } \\
\text { biphenyl-4- } \\
\text { yloxy]- } \\
\text { octanoic acid }\end{array}$ & & 0.023 & & & & \\
\hline
\end{tabular}


Table 2. Chemical structures and $\mathrm{IC}_{50}$ values of test set

\begin{tabular}{|c|c|c|c|c|c|}
\hline S.No & Structure & $I C_{50}$ & S.No & Structure & $I C_{50}$ \\
\hline B1 & $a-a-b r$ & 1.48 & B2 & & 1.69 \\
\hline B3 & & 0.53 & B4 & & 4.61 \\
\hline B5 & $a b \Rightarrow<$ & 2.40 & B6 & & 1.43 \\
\hline B7 & & 4.18 & B8 & & 0.82 \\
\hline B9 & & 2.04 & B10 & & 7.79 \\
\hline B11 & & 4.28 & B12 & & 3.87 \\
\hline B13 & & 2.28 & B14 & & 1.42 \\
\hline B15 & & 2.24 & B16 & & 7.46 \\
\hline B17 & & 1.91 & B18 & & 3.34 \\
\hline B19 & & 12.78 & B20 & & 2.11 \\
\hline B21 & & 2.60 & B22 & & 4.16 \\
\hline B23 & & 1.71 & B24 & & 2.39 \\
\hline B25 & & 1.34 & B26 & & 0.69 \\
\hline B27 & & 0.48 & B28 & & 3.66 \\
\hline B29 & & 1.26 & B30 & & 1.10 \\
\hline B31 & & 2.59 & B32 & & 1.24 \\
\hline B33 & & 2.55 & B34 & & 2.53 \\
\hline B35 & & 1.20 & B36 & & 1.86 \\
\hline B37 & & 0.32 & B38 & & 9.0 \\
\hline B39 & & 8.0 & B40 & & 5.0 \\
\hline B41 & & 15 & B42 & & 8.0 \\
\hline SB43 & & 14 & SB44 & & 15 \\
\hline
\end{tabular}




\begin{tabular}{|c|c|c|c|c|c|}
\hline B45 & & 5.0 & B46 & & 11 \\
\hline B47 & & 9.0 & B48 & & 6.0 \\
\hline B49 & & 1.1 & B50 & & 0.22 \\
\hline B51 & & 2.5 & B52 & $\sum_{3}^{1} r^{r}$ & 0.04 \\
\hline B53 & & 5 & B54 & & 8 \\
\hline B55 & & 0.08 & B56 & & 20 \\
\hline B57 & $\sum_{i=1} \sum_{\pi} \sum_{1}^{\infty}<$ & 0.005 & B58 & & 3.7 \\
\hline B59 & II & 0.13 & & & \\
\hline
\end{tabular}

\subsection{Molecular Docking Of Data Set With Target Proteins}

Molecular docking study was performed, with the aim of evaluating the most preferred geometry of protein-ligand complex. Docking phase is meaningless without its two components target protein and ligand.

3Q6E is used for performing docking study. Docking results identifies native or native-like configurations of the protein ligand complex. Insulin protein complex was used after removal of already binded Ligand and water molecules. Docking was done using software AutoDock 4.0 and its patch AutoDock Vina.

The complete docking steps could be stated as follows: first of all the water molecules were eliminated from the protein. After the removal of water molecules the pdb file of the macromolecule 3Q6E was provided as an input to the software. Kollman and Gasteiger charges were automatically computed for the macromolecule by AutoDock. Then the macromolecule was checked for the missing atoms and repaired. After repairing missing atoms, the hydrogens were added by keeping all the parameters at default settings. The macromolecule after all these modification was saved as .pdb in the same directory. Then the ligand preparation was carried out. Like macromolecule, Kollman and Gasteiger charges were computed for the ligand [39].The some of the torsions of the ligands were defined. The root was detected; the rotatable bonds were converted in to non rotatable bonds and vice versa and the number of active torsions was to most atoms rather than fewest. A pdbqt file was then created for the modified Ligand with extension .pdbqt. After the preparation of a macromolecule and ligand, rigid residue was prepared using GRID module provided in AutoDock 4.0 Grid module employed .pdb file. The flexible macromolecule was then saved with .pdbqt extension. For molecular docking AutoDock Vina software was used. Vina is an open source program with better speed than last version [40]. It employed a conf file referring pdbqt files of macromolecule and compounds prepared using AutoDock and Grid properties. As an output Vina generated log files and pdbqt files of energy models for selected data set. The output file contained different energy models. Among these models, the lowest energy model against each ligand was selected and appended at the end of original protein file. As a result of this step docked files for the selected set generated.

For the interpretation of docking results; target protein and protein docked with the data set of compounds, we need to find the interactions between the active pocket of protein and compounds.

Usually there are three types of interactions are studied;

- Hydrogen bonding,

- Ionic interactions

- Hydrophobic interactions

These interactions were studied by using Visual Molecular Dynamic (VMD) computer program .Interactions results within distance range of 4 were considered. All possible binding interactions were studied keenly in docked complex of target protein. 


\subsection{Lead Identification And Its Analogue Designing}

After finding interactions, most important step is lead identification. This was done on the basis of three things. Lead compound should be the most active compound having more number of interactions, less $\mathrm{IC}_{50}$ value, least binding Energy values of the model generated through docking. After selection of leads, Analogs are designed by introducing or removing different functional groups from the lead compound.

\section{Results And Discussion}

Molecular docking studies were carried out by using 59 compounds from test set along with 25 standard drugs. Target protein was used as molecular target. According to an estimate, docking programs dock $70-80 \%$ of ligands accurately [41]. Autodock Vina was employed for molecular docking studies. As a result of docking log file is generated; different conformations of the compounds docked into the target protein were obtained. For each ligand 10 different conformations have been generated .These conformations were automatically ranked in ascending order on the basis of the binding affinities of the ligand with the target protein. Among these conformations, the most active conformation was chosen based on the binding affinity of the ligand with the target protein for interaction analysis [42,43]. As the binding affinity is low compound best fits in the binding pocket of target protein.

Target protein has their active sites where the compound shows maximum number of interaction with protein. Complete data set was docked and found to bind at the same active site position. Amino acids are intimately involved in the binding ligand to protein and form a complex. The active site amino acids were identified by looking in the vicinity the $10^{\circ} \mathrm{A}$. The residue that is significant for binding interaction and thus comprising the binding pocket of target protein are: Asn 3, Val 2, Phe 1, His 5, His 10, Ile 10, Gln 4, Leu 6, Cys 11, Thr 8, Cys 7, Ser 9, Gly 8, Leu 13, Leu 16, Leu 17. Docking studies reveled that these amino acids present in the target proteins pocket involves in the binding interaction with the selected compounds.

Table 3 shows the list of all amino acids within 10A of the compounds docked with target. (+) Sign shows the presence of any amino acid and (-) sign shows the absence of amino acid in the docked complex of ligand.

Table 3. Amino Acids within $10^{\circ} \mathrm{A}$ of target protein present or absent in selected compounds

\begin{tabular}{|c|c|c|c|c|c|c|c|c|c|c|c|c|c|c|c|c|}
\hline $\begin{array}{l}\text { AMIN } \\
\text { O } \\
\text { ACID }\end{array}$ & $\begin{array}{l}\text { Asn } \\
3\end{array}$ & $\begin{array}{l}\text { Val } \\
2\end{array}$ & $\begin{array}{l}\text { Phe } \\
1\end{array}$ & $\begin{array}{l}\text { HIS } \\
5\end{array}$ & $\begin{array}{l}\text { His } \\
10\end{array}$ & $\begin{array}{l}\text { Ile1 } \\
0\end{array}$ & $\begin{array}{l}\text { Gln } \\
4\end{array}$ & $\begin{array}{l}\text { Leu } \\
6\end{array}$ & $\begin{array}{l}\text { Cys } \\
11\end{array}$ & $\begin{array}{l}\text { Thr } \\
8\end{array}$ & $\begin{array}{l}\text { Cys } \\
7\end{array}$ & $\begin{array}{l}\text { Ser } \\
9\end{array}$ & $\begin{array}{l}\text { Gly } \\
8\end{array}$ & $\begin{array}{l}\text { Leu } \\
13\end{array}$ & $\begin{array}{l}\text { Leu } \\
16\end{array}$ & $\begin{array}{l}\text { Leu } \\
17\end{array}$ \\
\hline S1 & - & - & - & - & - & - & - & - & - & - & + & - & + & - & - & + \\
\hline S3 & - & - & + & - & + & - & - & - & - & - & - & + & - & - & - & + \\
\hline S8 & - & + & - & + & + & - & + & + & - & - & - & - & - & + & + & - \\
\hline S12 & - & - & - & - & - & - & - & - & - & - & + & - & - & - & - & + \\
\hline S19 & - & - & - & - & + & - & - & - & + & - & - & - & - & + & - & + \\
\hline S21 & + & + & + & + & - & - & - & + & - & - & + & - & + & - & - & - \\
\hline B1 & + & - & - & + & - & + & + & + & + & - & - & - & - & + & + & + \\
\hline B2 & + & - & - & - & - & - & + & + & - & - & - & - & - & + & + & + \\
\hline B3 & - & - & - & - & - & - & + & - & - & - & + & - & + & - & - & + \\
\hline B6 & - & - & - & - & - & - & - & - & - & - & + & - & - & - & - & + \\
\hline B8 & - & - & - & - & - & - & + & + & - & - & - & - & - & - & - & - \\
\hline B9 & - & - & - & - & + & - & - & - & - & - & + & + & + & - & - & - \\
\hline B14 & - & - & - & - & - & - & - & + & - & - & + & - & + & - & - & + \\
\hline B17 & - & - & - & - & - & + & + & + & - & - & + & - & - & + & + & - \\
\hline B23 & - & + & - & + & + & - & - & + & - & - & + & + & + & - & - & - \\
\hline B25 & - & - & + & - & + & - & + & - & - & - & + & + & - & - & - & - \\
\hline B26 & + & + & + & + & - & + & - & - & - & - & + & + & - & - & - & - \\
\hline B27 & - & - & - & - & - & - & - & - & - & - & + & + & - & - & - & - \\
\hline B29 & + & - & + & + & + & - & - & - & - & - & - & - & - & - & - & - \\
\hline B30 & + & - & - & - & - & - & + & + & - & + & + & - & - & - & - & - \\
\hline B32 & - & + & - & + & + & - & - & + & - & - & + & + & - & - & - & - \\
\hline B35 & + & - & - & - & + & - & + & + & - & + & - & - & - & - & - & + \\
\hline B36 & - & - & - & - & - & - & - & - & - & - & + & - & + & - & - & + \\
\hline B37 & - & - & - & - & - & - & - & - & + & - & + & - & - & - & - & + \\
\hline B46 & + & + & + & + & + & + & + & - & + & - & + & - & - & - & - & - \\
\hline B49 & + & - & - & - & - & - & + & + & - & - & - & - & - & + & - & + \\
\hline B50 & - & - & - & - & + & - & - & + & - & - & - & - & - & & - & + \\
\hline B52 & - & - & - & - & - & - & - & - & - & - & - & - & - & + & - & + \\
\hline B55 & + & - & - & - & + & + & + & + & + & - & - & - & - & - & - & - \\
\hline B57 & + & - & - & + & + & - & + & + & - & - & - & - & - & + & - & + \\
\hline B59 & + & - & - & + & + & - & + & + & - & - & + & - & + & - & - & + \\
\hline
\end{tabular}


Human protein target was used to dock with the compound of test set. Best confirmation of each compound was selected on the basis of binding affinity. The interactions of the active conformations of the compounds of the selected data and the target protein have been identified and marked using VMD and are shown in table 4. Compounds were selected on the basis on least inhibition concentration $\mathrm{IC}_{50}$ values.VMD provides the facility of labeling and computing distances between atoms of selected compounds with protein pocket. Checking one by one all amino acids in the active site of target and atoms of the compounds, the interactions were identified. Checking one by one all amino acids in the active site of target and atoms of the compounds, the interactions were identified. The important indentified interactions in a data set include the ionic, hydrogen and hydrophobic interactions, avoiding the mistakes was the most important step of this study. The amino acids with in $10^{\circ} \mathrm{A}$ have been shown in fig 2 and 3 . The amino acids present within $10^{\circ} \mathrm{A}$ of the pocket have been involved in the binding interactions. Ligand is in Bonds representation and the protein residues are in line representation in images of docked complex are shown in figure fig 2 and 3.

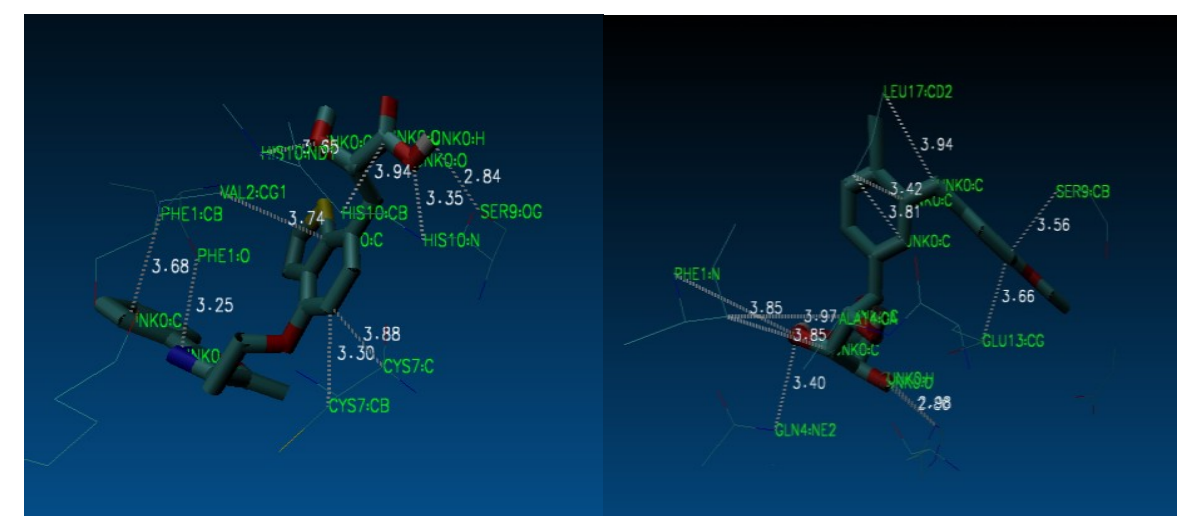

Figure 2. Binding interaction of docked standard compounds 1(a) and 3(b) within active site of $10 \mathrm{~A}^{\circ}$.

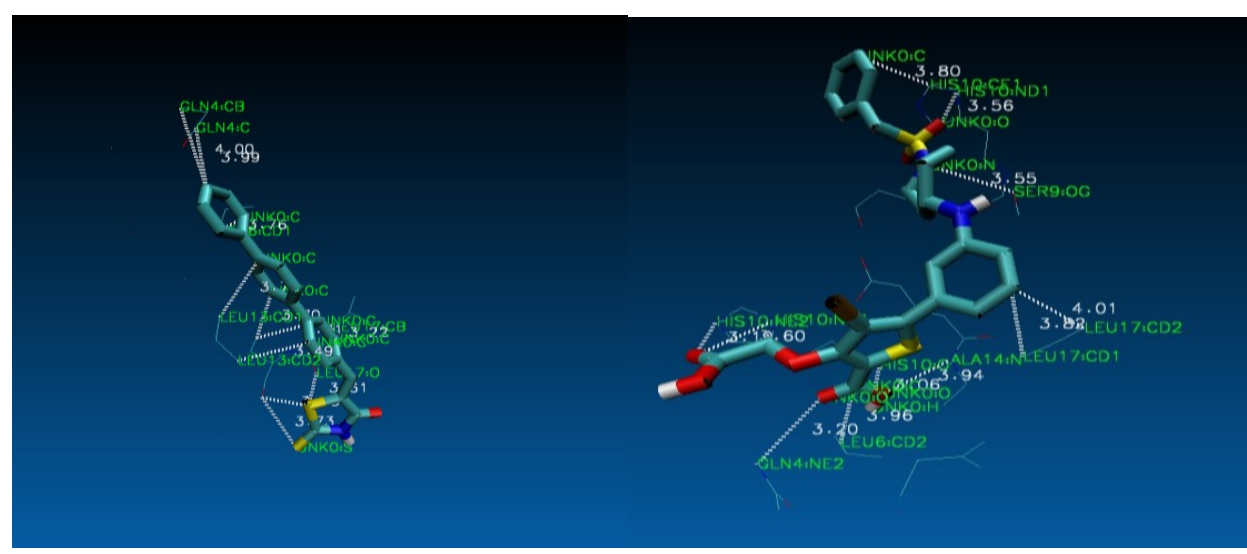

Figure 3. Binding interaction of docked compounds B2 (a) and B58 (b) of test set within active site of $10 \mathrm{~A}^{\circ}$.

Table 4 enlists all three types of interactions of the two selected drugs from set of 25 standard drugs. All interactions are calculated very carefully along with the distance between ligand and protein pocket active residues. The interaction includes hydrogen bonding, ionic bonding and hydrophobic interactions. Hydrogen bond is formed when hydrogen binds with either oxygen or nitrogen. When oxygen forms a bond with nitrogen, it gives ionic bonding. Hydrophobic interaction is considered when carbon binds with carbon of other molecule.

Figure 2 shows the hydrogen, hydrophobic and ionic interactions of the standard drugs. These interactions will be then compared with the selected lead compound. Docking of Aleglitazar (S1) with the protein gave number of interactions that include, 2 hydrogen and 8 hydrophobic. Hydrogen of Aleglitazar forms bond with Oygen of Leu 17 at distance of $2.16^{\circ} \mathrm{A}$ and Hydrogen of Aleglitazar forms bond with Oygen of Tyr 16 at distance of $3.39^{\circ} \mathrm{A}$. The hydrophobic interactions includes Carbon of Gly 8 at distance of $3.66^{\circ} \mathrm{A}$, Tyr 16 at $3.93^{\circ} \mathrm{A}$, Tyr 16 with other Carbon of ligand at $3.49^{\circ} \mathrm{A}$, Gly 20 at $3.66^{\circ} \mathrm{A}$, Gly 20 with other Carbon of ligand at $3.97^{\circ} \mathrm{A}$, Val 3 at $3.79^{\circ} \mathrm{A}$ and Tyr 16 at $3.82^{\circ} \mathrm{A}$. Docking of Dapagliflozin (S3) includes binding interactions includes 12 hydrogen bonding, 1 ionic bonding and 3 hydrophobic interactions. Hydrogen bonding includes Nitrogen of His 10 forms bond with oxygen of ligand at distance of $3.74^{\circ} \mathrm{A}$ with the other oxygen of ligand form bond with His 10 with distance of $3.26^{\circ} \mathrm{A}$ Oxygen of His 5 bonded with Hydrogen at $3.48^{\circ} \mathrm{A}$, oxygen of His 5 
bonded with other Hydrogen at $2.00^{\circ} \mathrm{A}$, nitrogen of Ser 9 bonded with oxygen at $2.97^{\circ} \mathrm{A}$, nitrogen of Leu 6 bonded with oxygen at $3.97^{\circ} \mathrm{A}$, nitrogen of Cys 7 bonded with oxygen at $2.86^{\circ} \mathrm{A}$. Nitrogen of Cys 7 bonded with hydrogen at $3.30^{\circ} \mathrm{A}$, nitrogen of Leu 17 bonded with hydrogen at $3.50^{\circ} \mathrm{A}$, nitrogen of Val 2 bonded with hydrogen at $3.31^{\circ} \mathrm{A}$, nitrogen of $\mathrm{Val} 2$ bonded with oxygen at $3.31^{\circ} \mathrm{A}$, Oxygen of Val 2 bonded with hydrogen at $2.59^{\circ} \mathrm{A}$ and oxygen of Phe 1 bonded with hydrogen at distance of $2.59^{\circ} \mathrm{A}$. Ionic interaction is between nitrogen of His 10 and hydrogen of ligand at distance $3.43^{\circ} \mathrm{A}$. Hydrophobic interactions include; carbon of Cys 7 makes bond with carbon of ligand at different positions at distance $3.79^{\circ} \mathrm{A}, 3.69^{\circ} \mathrm{A}$ and $3.84^{\circ} \mathrm{A}$. Docking results ligand S3, S8 and S21 shows hydrogen bonding else shows strong hydrophobic interactions and hydrogen bonding. S21 shows strong hydrogen bonding with target protein.

Table 4. Binding interaction of selected compounds within $10^{\circ} \mathrm{A}$ of the target protein pocket:

\begin{tabular}{|c|c|c|c|c|c|c|c|}
\hline \multirow[b]{2}{*}{$\begin{array}{l}\text { Ligand } \\
\text { No }\end{array}$} & \multicolumn{2}{|c|}{ Hydrogen Bonding } & \multicolumn{2}{|c|}{ Ionic Interactions } & \multicolumn{2}{|c|}{ Hydrophobic Interactions } & \multirow{2}{*}{$\begin{array}{l}\text { Bindin } \\
\text { g } \\
\text { Energy } \\
\text { (Kcal/ } \\
\text { mol) } \\
\end{array}$} \\
\hline & Amino Acids & Distance & Amino acids & Distance & Amino Acids & Distance & \\
\hline S1 & $\begin{array}{l}\text { H-LEU17: O } \\
\text { H-TYR16: O }\end{array}$ & $\begin{array}{l}2.16 \\
3.39\end{array}$ & None & & $\begin{array}{l}\text { C-GLY8:CA } \\
\text { C-TYR16:CZ } \\
\text { C-TYR16:CE1 } \\
\text { C-GLY20:C } \\
\text { C-GLY20:CA } \\
\text { C-VAL3:CG2 } \\
\text { C-TYR16:CE2 }\end{array}$ & $\begin{array}{l}3.66 \\
3.93 \\
3.49 \\
3.66 \\
3.97 \\
3.79 \\
3.82 \\
\end{array}$ & -7.4 \\
\hline $\mathbf{S 3}$ & $\begin{array}{l}\text { O-PHE1:N } \\
\text { O-GLN4:NE2 } \\
\text { O-HIS10:ND1 }\end{array}$ & $\begin{array}{l}3.85 \\
3.40 \\
2.80\end{array}$ & H-HIS10:ND1 & 2.89 & $\begin{array}{l}\text { C-SER9:CB } \\
\text { C-LEU17:CD2 } \\
\text { C-LEU17:CD1 } \\
\text { C-LEU17:CD1 } \\
\text { C-ALA14:CA } \\
\text { C-ALA14:CA } \\
\text { C-GLU13:CG }\end{array}$ & $\begin{array}{l}3.56 \\
3.94 \\
3.42 \\
3.81 \\
3.97 \\
3.85 \\
3.66 \\
\end{array}$ & -6.7 \\
\hline B1 & H-GLN4:O & 3.04 & None & & $\begin{array}{l}\text { C-LEU6:CDI } \\
\text { C-ALA14:CB } \\
\text { C-VAL18:CG2 } \\
\text { C-LEU17:CB }\end{array}$ & $\begin{array}{l}3.72 \\
3.91 \\
3.48 \\
3.44 \\
\end{array}$ & -7.1 \\
\hline B2 & $\begin{array}{l}\text { S-LEU17: O } \\
\text { S-VAL18: O } \\
\text { S-VAL18: O }\end{array}$ & $\begin{array}{l}3.61 \\
3.73 \\
3.63\end{array}$ & None & & $\begin{array}{l}\text { C-GLN4:CB } \\
\text { C-LEU4:C } \\
\text { C-LEU6:CD1 } \\
\text { C-VAL18:CG2 } \\
\text { C-VAL18:CG2 } \\
\text { C-LEU17:CB } \\
\text { C-LEU13:CD2 } \\
\text { C-LEU13:CD }\end{array}$ & $\begin{array}{l}4.00 \\
3.99 \\
3.76 \\
3.71 \\
3.70 \\
3.22 \\
3.49 \\
3.76 \\
\end{array}$ & -6.8 \\
\hline B3 & H-GLU4:OE2 & 3.12 & H-GLU4:OE1 & 4.00 & $\begin{array}{l}\text { C-LEU17:C } \\
\text { C-LEU17:C } \\
\text { C-VAL3:CG1 } \\
\text { C-LEU17:CD2 } \\
\text { C-TYR16:CZ }\end{array}$ & $\begin{array}{l}3.97 \\
3.92 \\
3.64 \\
3.75 \\
3.75 \\
\end{array}$ & -6.7 \\
\hline B6 & F-GLU21:OE2 & 3.72 & None & & $\begin{array}{l}\text { C-LEU17:CA } \\
\text { C-LEU16:CZ } \\
\text { C-VAL3:CG1 } \\
\text { C-VAL3:CG1 } \\
\text { C-CYS7:CB } \\
\text { C-LEU13:CD2 }\end{array}$ & $\begin{array}{l}3.94 \\
3.56 \\
3.87 \\
3.06 \\
3.94 \\
3.59 \\
\end{array}$ & -6.8 \\
\hline B57 & $\begin{array}{l}\text { O-HIS10:ND1 } \\
\text { N-SER9:OG } \\
\text { O-HIS10:ND1 } \\
\text { O-HIS10:NE2 } \\
\text { O-ALA14:N } \\
\text { HN-HIS10:O } \\
\end{array}$ & $\begin{array}{l}3.56 \\
3.55 \\
3.60 \\
3.19 \\
3.94 \\
3.06 \\
\end{array}$ & None & & $\begin{array}{l}\text { C-HIS10:CE1 } \\
\text { C-LEU17:CD1 } \\
\text { C-LEU17:CD2 } \\
\text { C-LEU6:CD2 }\end{array}$ & $\begin{array}{l}3.80 \\
3.82 \\
4.00 \\
3.96\end{array}$ & -7.3 \\
\hline B58 & $\begin{array}{l}\text { O-HIS10:ND1 } \\
\text { HN-SER9:OG } \\
\text { O-HIS10:ND1 } \\
\text { O-HIS10:NE2 } \\
\text { O-ALA14:N } \\
\text { HN-HIS10:O } \\
\end{array}$ & $\begin{array}{l}3.56 \\
3.55 \\
3.60 \\
3.19 \\
3.94 \\
3.06 \\
\end{array}$ & None & & $\begin{array}{l}\text { C-HIS10:CE1 } \\
\text { C-LEU17:CD1 } \\
\text { C-LEU17:CD2 } \\
\text { C-LEU6:CD2 }\end{array}$ & $\begin{array}{l}3.80 \\
3.82 \\
4.00 \\
3.96\end{array}$ & -7.3 \\
\hline
\end{tabular}

Techniques followed for lead identification was reported by Eli Lilly in his research. Lead was identified and was later further optimized [44]. The binding interactions of all compounds have been analyzed. On the basis of the strong interaction, least value of inhibition concentration $\left(\mathrm{IC}_{50}\right.$ value $)$ and binding 
energy lead compound has been identified.Analogs of this compound has been made in order to get the possible and most active compounds to use as antidiabetic drugs. Table 5 shows the analogs made by changing the functional groups in order an active compound on the basis of efficacy. From lead to designed analogue compounds need to be test for its ADMET properties.

Fig 3(b) shows the interactions of lead compound docked target protein. Lead compound is represented in bonds formation, Red color shows the hydrogen bond acceptor and blue color shows the hydrogen bond donor. White color shows the hydrogen bond and yellow is representing the electronegative compounds like halogens. Four Analogus were suggested after the thorough study of lead compound. Table 5 shows the Analogus of lead compound with their IUPAC names generated by ChemDraw Ultra 8.0.these Analogus have been made by the introduction or removal of various functional groups or replacement of one group with any other group present in the structure of lead compound. In the first analogue halogen group is added Br has been introduced in the group this will increase the hydrogen bonding. Second analogue is made by the introduction of $\mathrm{CH}_{3}$ (methyl group) known as $\mathrm{C}$-alkylation and makes an ester derivative which will enhance the hydrophobicity in compound. Third analogue is made by the reduction of double bonds of benzene ring to single bond which will increase hydrophobicity in compound. A fourth analogue is made by the reduction of carboxyl group which will improve the hydrophobic character of the compound. As the target protein is hydrophobic in nature these Analogus results show the better interaction as compared to the other compounds tested before.

Table 6 shows the maximum number of interactions and binding affinities of Analogus set with amino acid within $10^{\circ} \mathrm{A}$ of the target protein pocket.

Table 5. Analogus of the lead Compound along the IUPAC Names and structures

\begin{tabular}{|c|c|c|c|}
\hline S.No & FGI & IUPAC Name & Structure \\
\hline 1 & Bromination & $\begin{array}{l}\text { 4-Bromo-5-\{3-[1-(4-bromo- } \\
\text { phenylmethanesulfonyl)-piperidin-4-ylamino]- } \\
\text { phenyl)-3-carboxymethoxy-thiophene-2-carboxylic } \\
\text { acid }\end{array}$ & \\
\hline 2 & Ester Derivatives & $\begin{array}{l}\text { 4-Bromo-3-methoxycarbonylmethoxy-5-[3-(1- } \\
\text { phenylmethanesulfonyl-piperidin-4-ylamino)- } \\
\text { phenyl]-thiophene-2-carboxylic acid }\end{array}$ & \\
\hline 3 & $\begin{array}{l}\text { Reduction of } \\
\text { Aromatic Ring }\end{array}$ & $\begin{array}{l}\text { 4-Bromo-3-carboxymethoxy-5-[3-(1- } \\
\text { cyclohexylmethanesulfonyl-piperidin-4-ylamino0- } \\
\text { phenyl]-thiophene-2-carboxylic acid }\end{array}$ & \\
\hline 4 & $\begin{array}{c}\text { Reduction of } \\
\text { Carboxyl Group }\end{array}$ & $\begin{array}{l}\text { \{4-Bromo-2-hydroxymethyl-5-[3-(1- } \\
\text { phenylmethanesulfonyl-piperidin-4-ylamino)- } \\
\text { phenyl]-thiophen-3-yloxy\}-acetic acid }\end{array}$ & \\
\hline
\end{tabular}

Table6: Interactions and binding affinities of Analogus with amino acid within $10^{\circ} \mathrm{A}$ of the target protein pocket:

\begin{tabular}{|c|c|c|c|c|c|c|c|}
\hline Ana-logs & \multicolumn{2}{|c|}{ Hydrogen Bonding } & \multicolumn{2}{|c|}{ Ionic Interaction } & \multicolumn{2}{|l|}{$\begin{array}{l}\text { Hydrophobic } \\
\text { Interactions }\end{array}$} & \multirow{2}{*}{$\begin{array}{l}\text { Bindin } \\
\text { g } \\
\text { Affinit } \\
\mathbf{y} \\
-7.0\end{array}$} \\
\hline 1 & $\begin{array}{l}\text { S-TYR16:OH } \\
\text { H-GLU21:OE2 } \\
\text { H-TYR26:OH }\end{array}$ & $\begin{array}{l}3.64 \\
3.99 \\
3.77\end{array}$ & None & & $\begin{array}{l}\text { C-LEU17:CD2 } \\
\text { C-HIS10:CE1 } \\
\text { C-TYR26:OH } \\
\text { C-TYR16:CE1 }\end{array}$ & $\begin{array}{l}3.65 \\
4.00 \\
3.77 \\
3.76\end{array}$ & \\
\hline 2 & $\begin{array}{l}\text { O-ARG22:NH2 } \\
\text { O-ARG22:NE } \\
\text { S-VAL18:O } \\
\text { H-CYS19:O } \\
\text { BR-GLY17:OE2 }\end{array}$ & $\begin{array}{l}3.21 \\
3.10 \\
3.31 \\
3.15 \\
3.63\end{array}$ & $\begin{array}{l}\text { H-GLU21:N } \\
\text { H- } \\
\text { ARG22:NE }\end{array}$ & $\begin{array}{l}3.52 \\
3.52\end{array}$ & $\begin{array}{l}\text { C-VAL18:CA } \\
\text { C-LEU17:C } \\
\text { C-LEU17:CB } \\
\text { C-LEU17:CD1 } \\
\text { C-LEU6:CD1 } \\
\text { C-LEU6:CG } \\
\text { C-LEU13:CD1 }\end{array}$ & $\begin{array}{l}3.51 \\
3.94 \\
3.70 \\
3.82 \\
3.68 \\
3.77 \\
3.66 \\
\end{array}$ & -7.6 \\
\hline 3 & $\begin{array}{l}\text { H-SER9:OG } \\
\text { H-SER9:N } \\
\text { O-SER9:N }\end{array}$ & $\begin{array}{l}3.22 \\
3.31 \\
3.52\end{array}$ & None & & $\begin{array}{l}\text { C-GLY8:CA } \\
\text { C-LAL3:CG1 } \\
\text { C-TWR8:CG2 } \\
\text { C-THR8:CG2 }\end{array}$ & $\begin{array}{l}3.64 \\
3.97 \\
3.79 \\
3.67\end{array}$ & -7.3 \\
\hline 4 & $\begin{array}{l}\text { O-GLU21:N } \\
\text { O-ARG22:NH2 } \\
\text { H-GLU17:OE2 } \\
\text { S-VAL18:O }\end{array}$ & $\begin{array}{l}3.42 \\
3.55 \\
3.74 \\
3.55\end{array}$ & None & & $\begin{array}{l}\text { C-VAL3:CG1 } \\
\text { C-PRO28:CB } \\
\text { C-PRO28:CG } \\
\text { C-LEU17:CD2 }\end{array}$ & $\begin{array}{l}4.0 \\
3.30 \\
4.00 \\
3.88\end{array}$ & -7.6 \\
\hline
\end{tabular}




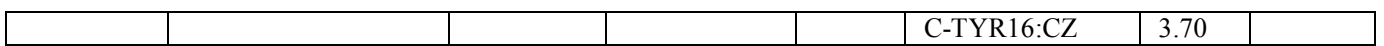

Ligand based approach was applied for in silico screening for novel antidiabetic compounds possessing the strong binding interactions, hit-to-lead compounds were designed named as 4-Bromo-5-\{3-[1-(4-bromophenylmethanesulfonyl)-piperidin-4-ylamino]-phenyl)-3-carboxymethoxy-thiophene-2-carboxylic acid, 4Bromo-3-methoxycarbonylmethoxy-5-[3-(1-phenylmethanesulfonyl-piperidin-4-ylamino)-phenyl]-thiophene-2carboxylicacid,4-Bromo-3-carboxymethoxy-5-[3-(1-cyclohexylmethanesulfonyl-piperidin-4-ylamino0-phenyl]thiophene-2-carboxylic acid and \{4-Bromo-2-hydroxymethyl-5-[3-(1-phenylmethanesulfonyl-piperidin-4ylamino)-phenyl]-thiophen-3-yloxy\}-acetic acid are shown in table 5.

\section{Conclusion}

The current study was aimed at finding novel drug like molecules as antidiabetic compounds using in silico approach. Intermolecular interactions between target protein binding site of target and different antidiabetic compounds were observed. The purpose of this study was to evaluate therapeutic applications of antidiabetic compounds through molecular docking. In short this study reveals that in silico approaches were used to discover lead compound and its analogues that lend a hand in inhibiting diabetes mellitus.

\section{Refrences}

[1]. Patel DK, Kumar R, Prasad SK, Sairam K, Hemalatha S, Anti-diabetic and in vitro antioxidant potential of Hybanthus enneaspermus (Linn) F. Muell in streptozotocin-induced diabetic rats. Asian Pacific Journal of Tropical Biomedicine, 1(4), 2011, pp 316-22.

[2]. Warjeet Singh L, Traditional medicinal plants of Manipur as anti-diabetics, Journal of Medicinal Plants Research, 5(5), 2011, pp 677-87.

[3]. Chauhan A, Sharma PK, Srivastava P, Kumar N, Dudhe R, Plants having potential anti-diabetic activity,A review. Der Pharmacia Lettre, 2(3), 2010, pp 369-87.

[4]. Notkins, A.L, Immunologic and genetic factors in type 1 diabetes, The Journal of Biological Chemistry.277, 2002, pp 43545-43548.

[5]. Hui H, Tang G, Go VL, Hypoglycemic herbs and their action mechanisms. Chinese Medicine, 4, $2009,4-11$.

[6]. Neustadt J, Pieczenik SR., Medication-induced mitochondrial damage and disease. Molecular Nutrition \& Food Research, 52(7), 2008, pp 780-788.

[7]. Mooradian, A. D. and Thurman, J. E, Drug therapy of postprandial hyperglycaemia. Drugs, 57, (1999),pp 19-29.

[8]. Jung M, Park M, Lee HC, Kang YH, Kang ES, Kim SK., Anti-diabetic agents from medicinal plants. Current Medicinal Chemistry, 13, 2006,pp1203-18.

[9]. Donath MY, Ehses JA., Type I and type II diabetes: NOD the diabetes we thought it was. Proceedings of the National Academy of Sciences, 103, 2006, pp 12217-12218.

[10]. Noor A, Gunasekaran S, Manickam AS, Vijayalakshmi MA., Antidiabetic activity of Aloe Vera and histology of organs in STZinduced diabetic rats. Current Science, 94, 2008, pp 1070-1076.

[11]. Hansotia T, Drucker DJ., GIP and GLP-1 as incretin hormones: lessons from single and double incretin receptor knockout mice. Regulatory Peptides, 128, 2005, pp 125-134.

[12]. Pepato MT, Mori DM, Baviera AM, Harami JB, Vendramini RC, Brunetti IL., Fruit of the jambolantree (Eugenia jambolana) and experimental diabetes. Journal of Ethnopharmacology, 96, 2005, pp 43-48.

[13]. Tanaka M, Misawa E, Ito Y, Habara N, Nomaguchi K, Yamada M, Toida T, Hayasawa H, Takase M, Inagaki M, Higuchi R., Identification of five phytosterols from Aloe Vera gel as antidiabetic compounds. Biological and Pharmaceutical Bulletin, 29, 2006,pp 1418-1422.

[14]. Sharma SB, Nasir A, Prabhu KM, Murthy PS., Anti-hyperglycemic Effect of the fruit-pulp of Eugenia jambolana in experimental diabetes mellitus. Journal of Ethnopharmacology , 104, 2006, pp 367-373.

[15]. Guttula, S.V., Appa Rao, A., Sridhar G.R., and Chakravarthy, M.S., Protein ligand interaction analysis an insilico potential drug target identification in diabetes mellitus and nephropathy. Joint Base San Antonio, 2, 2011, pp 095-99.

[16]. Ganugapati, J., Mukkavalli, S., \& Sahithi, A. Docking Studies of Green Tea Flavonoids as Insulin Mimetics. International Journal of Computers and Their Applications, 30, 2011, pp 48-51.

[17]. Lessard, L., Stuible, M., \& Tremblay, M.L., The two faces of PTP1B in cancer. Biochimica et Biophysica Acta, 1804, 2010, pp 613-9.

[18]. Zhang, S. Computer-aided drug discovery and development. Methods in molecular biology, 716, 2011, pp 23-38.

[19]. Rattinger, G., \& Bero, L, Factors associated with results and conclusions of trials of thiazolidinediones. Plos One, 4(6), 2009, e5826.

[20]. Liu, Z., Huang, Y., Zhang W, Ma LP, Li JY, \& Wang X. Soluble polymer-supported synthesis of 5-arylidene thiazolidinones and pyrimidinones using a novel traceless linker strategy. Journal of Combinatorial Chemistry, 10, 2008, pp 632-6.

[21]. Pozzan, A. Molecular descriptors and methods for ligand based virtual high throughput screening in drug discovery. Current Pharmaceutical Design, 12(17), 2006, pp 2099-2110.

[22]. Wang, J., Kollman, P.A., \& Kuntz, I.D. Flexible ligand docking: a multistep strategy approach. Protien,36(1), 1999, pp 1-19.

[23]. Muegge, I., Rarey, M. Small molecule docking and scoring.Review in Computational Chemistry, 17, 2001, pp 1-60.

[24]. Shoichet, B.K., McGovern, S.L., Wei, B., \& Irwin, J.J. Lead discovery using molecular docking. International Journal of Molecular Sciences, 6(4), 2002, pp 439-46.

[25]. Halperin, I., Ma, B., Wolfson, H., \& Nussinov, R. Principles of docking: An overviewof search algorithms and a guide to scoring functions. Proteins, 47, 2002, pp 409-443.

[26]. Brooijimans, N. and Kuntz, I.D., Molecular recognition and docking algorithms. Annual Review of Biophysics and Bimolecular Structure, 32, 2003,pp 335-373.

[27]. Kitchen, D.B., Decornez, H., Furr, J.R., \& Bajorath, J. Docking and scoring in virtual screening for drug discovery: Methods and applications. Nature Reviews Drug Discovery, 3, 2004, pp 935-948.

[28]. Sousa, S.F., Fernandes, P.A., \& Ramos, M.J. Protein-ligand docking: Current status and future challenges. Proteins, 65, 2006, pp 15-26. 
[29]. Kolb P, Ferreira RS, Irwin JJ, Shoichet BK., Docking and chemoinformatic screens for new ligands and targets. Current Opinion in Biotechnology, 20, 2009, pp 429-436.

[30]. Semighini, E.P., Resende, J.A., de Andrade, P., Morais, P.A., Carvalho, I., Taft, C.A., \& Silva, C.H. Using computer-aided drug design and medicinal chemistry strategies in the fight against diabetes. Journal of biomolecular structure \& dynamics, 28, 2011, pp 787-796.

[31]. K.R. Cousins, “ChemDraw Ultra 9.0. Cambridge soft, 100 Cambridge ParkDrive, Cambridge, MA 02140,” J.Am.Chem.Soc., 127, 2005, pp. 4115-4116.

[32]. Chang MW, Ayeni C, Breuer S, Torbett BE, Virtual Screening for HIV Protease Inhibitors: A Comparison of AutoDock 4 and Vina, PLoS ONE 5(8), 2010, e11955.

[33]. Humphrey W, Dalke A, Schulten K, VMD: visual molecular dynamics. J Mol Graph, 14, 1996, pp. 33-38.

[34]. Chinai, J.M., Taylor, A.B., Ryno, L.M., Hargreaves, H.D., Morris, C.A., Hart, P.H. , \& Urbach, A.R. Molecular Recognition of Insulin by a Synthetic Receptor, Journal of the American Chemical Society, 15, 133(23), 2011, pp 8810-8813.

[35]. Ferreira CV, Justo GZ, Souza ACS, Queiroz KCS, Zambuzzia WF, Aoyama H, Peppelenbosch MP Natural compounds as a source of protein tyrosine phosphatase inhibitors: Application to the rational design of small-molecule derivatives. Biochimie 88, 2006, pp 1859-1873.

[36]. Bhattarai BB, Kafle B, Hwang JS, Khadka D, Lee SM, Kang JS, Ham SW, Han IO, Park H, Cho H Thiazolidinedione derivatives as PTP1B inhibitors with antihyperglycemic and antiobesity effects. Medi Chem Lett, 19, 2009, pp 6161-6165.

[37]. Vintonyak VV, Waldmann H, Rauh D Using small molecules to target protein phosphatases. Bio organ Medicine Chem. 19, 2011, pp 2145-2155.

[38]. Jain AK, Vaidya A, Recent developments and biological activities of thiazolidinone derivatives: A review. Bio org Med Chem. 2012, Pp xxx xxx-Xxx.

[39]. Mills N, ChemDraw Ultra 8.0, Journal of the American Chemical Society, 128(41), 2006, pp 13649-13650.

[40]. Gasteiger J, Marsili M , Iterative partial equalization of orbital electronegativity-a rapid access to atomic charges. Tetrahedron 36, 1980, pp 3219-3228.

[41]. Trott O.,and Olson A. J., AutoDock vina:Improving the speed and Accuracy of Docking with a New Scoring Function ,Efficent Optimization, and Multithreading, journal of computational chemistry, 31, 2010, pp 445-461.

[42]. Cavasotto, C.N., \& Orry, A.J. Ligand docking and structure-based virtual screening in drug discovery.Current Topic Medicnal Chemistry, 7, 2007,pp 1006-1014.

[43]. Noureen N,Rashid H,Kalsoom S. An efficient anticancer histone deacetylase inhibitor and its analogues for human HDAC8, Medicinal Chemistry Research. 2012, 21(5),pp 568-577.

[44]. Khalid A, Kalsoom S,Riaz N, Design and Molecular Docking of Antioxidant Lead Compound and its Analogues Acting as Human Tyrosine Kinase Inhibitors, IOSR Journal of Pharmacy and Biological Sciences ,5(4), 2013,pp 75-80.

[45]. Sawyer, J.S. Synthesis and activity of new aryl- and heteroaryl-substituted pyrazole inhibitors of the transforming growth factorbeta type I receptor kinase domain. Journal of medicinal chemistry, 46(19), 2003,pp 3953-6. 